\title{
Statistical equation modeling analysis for industrial projects, designing for critical factors and latent variables: quality, cost, time, and success
}

\author{
Humberto García ${ }^{1} \cdot$ Adán Valles $^{2} \cdot$ Jaime Sánchez $^{1} \cdot$ Salvador Noriega $^{1}$. \\ Gustavo Dominguez ${ }^{1}$
}

Received: 14 October 2015 / Accepted: 23 March 2016/Published online: 30 April 2016

(C) The Author(s) 2016. This article is published with open access at Springerlink.com

\begin{abstract}
The literature and viewed items on this subject show no statistical data examination regarding the relationship or approach between critical factors (CF) and their association or significance for project evaluation and corroborate for successful realization. Executives, project managers, and staff members have no statistical data on the matter and importance regarding $\mathrm{CF}$, the influence for the possible outcomes, and scenarios; these factors and criteria yield neither a basic structural model on project management nor achievement rationale to conduct their time, process standards, efforts, and resources. For this work, we analyzed the basic formats of scientific articles under definite and established methods to develop a scientific study and strategies to determine an evaluated structural model, with the goal analysis methodology for the management on industrial projects, identifying sequence patterns, articles, classification factors, calculations frequency factors, and
\end{abstract}

Humberto García

hugarcia_2000@yahoo.com

1 Professor at Industrial engineering department, Ciudad Juarez Institute of Technology, Ave. Tecnológico No. 4090, Cd. Juarez, Chihuahua, Mexico

2 Research professor at Industrial engineering department, Ciudad Juarez Institute of Technology, Cd. Juarez, Chihuahua, Mexico statistical relationships between them, within the proposed path diagram structural model, simulated and exanimated regarding success.

Keywords Critical factors (CF) · Evaluation criteria · Meta-analysis · Structural modeling · Project management . Exploratory factor analysis $\cdot$ Confirmatory factor analysis . Latent variables

\section{Introduction}

It is pertinent noting some definitions for project characterization by the reviewed bibliography, first it is a temporary endeavor undertaken to create a unique product or service [1] (Project Management Institute, 2004). Two concepts are interrelated on the strategic planning processes, which most often get different interpretations and practical applications: critical success factors (CSFs) and key result areas (KRA).

The most effective use of CSF is for consulting work experience, to identify the critical factors for positioning and competitiveness in a determined business (industry). They can serve to analyze their influence and "Know how" of successful competitors (competitive benchmarking), from this, determine strategies, policies, and actions to overcome them.

Therefore, it is important to analyze literature through some definite methods, then check the critical factors which are most important in the management of projects, this paper uses meta-analysis (MA) methodology 


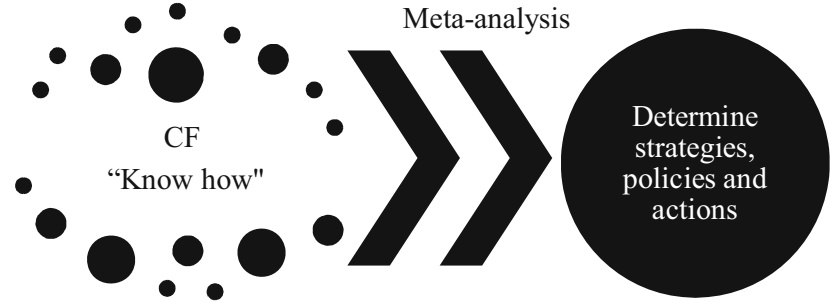

Fig. 1 Propose method

and basic descriptive statistics to show differences in the relationship between groups of factors, as shown in Fig. 1.

\section{Methods}

Meta-analysis takes a large quantity of quantitative extracted results on individual investigations, with the purpose of outcome integration and improve understanding, this systematic revision tries to reach conclusions from a variety of studies on the same subject, by analyzing procedures and standardized techniques. This statistical method is fundamental to delimitate the success criteria for industrial projects.

There is no single method for MA preparation, particular studies excludes or adds some stages; however, definite steps are listed next and make the algorithm followed in this study [2] (Valles, 2008).

The methodology consists of six stages which are next shown in Fig. 2.

Table 1 shows the result of applying meta-analysis to a sample data base of 85 articles and publications where there were found up to 27 critical factors for project management.

\subsection{Definition of structural equation modeling (SEM)}

This technique applies factor analysis with linear regression too test the observed goodness of fit from the collected data that conforms to a hypothesized model, this mathematical model is also expressed by a path diagram. SEM provides coefficients for each relationship, and most importantly, statistical indexes that express the degree to which the data fits the proposed model, confirming its validity.

Among the strengths of SEM is the ability to construct latent variables, which are not directly measured, but are estimated from a number of variables and their mutual covariance within the model, allowing it to capture the reliability of the model. Factor analysis, path analysis, and linear regression represent special cases

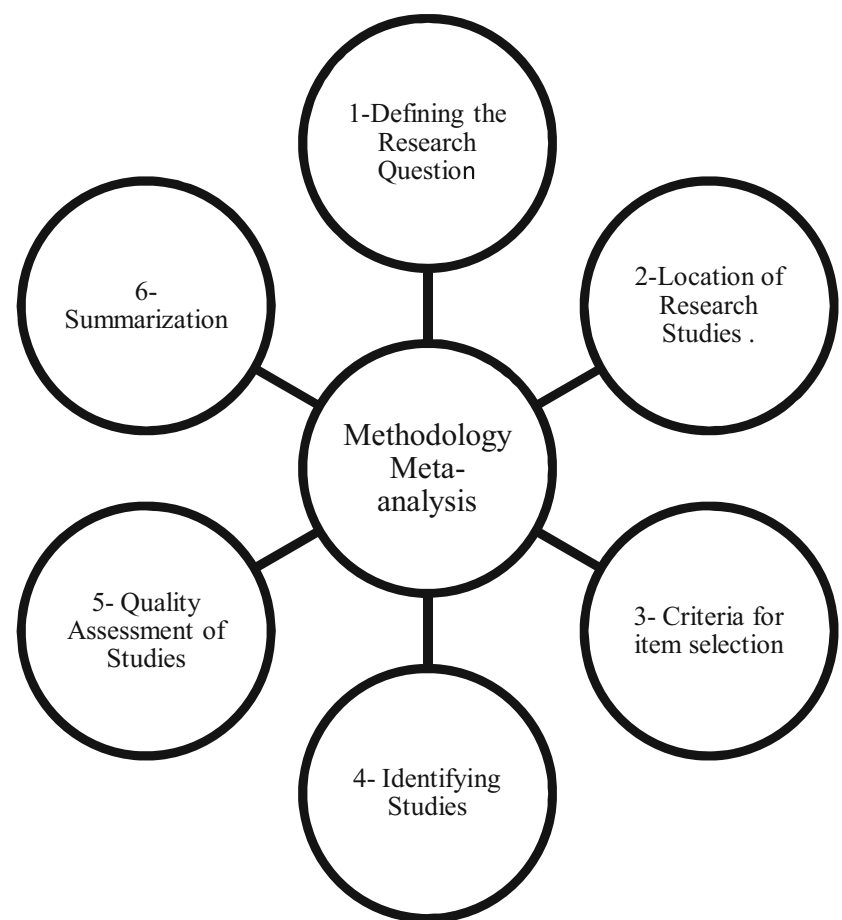

Fig. 2 Methodologies [3] (Colín, 2007)

for structural equation modeling [4] (Iacobucci, 2010). It is a statistic destined for testing and estimating causal relations from statistical data and qualitative causal assumptions [5] (Iacobucci, 2009).This definition has been articulated by the geneticist Sewall [6] (Wright, 1999).

SEM was born from the need to offer more flexibility for the regression models. It is less restrictive than the regression models, allowing the handler to include error measurements in both subordinate variables (dependent) as the predictor (independent) variables. The structural equation modeling methodology is a fresh area for developing statistics regression models, including factor analysis. SEM has a confirmatory nature more than an exploratory a major strength is the ability to develop constructs that estimate latent variables based around measurable variables.

Figure 3 and Table 2 show a path diagram graphic array and for the table the notation used for each element within the path diagram and SEM methodology; this is a representation for a set of equations.

\subsection{Applying the statistical analysis methodology SEM}

Tables 3, 4, and 5 show the CF covariance and correlation among factors, for each of the three criteria evaluated: finish on time the industrial project, fulfill the budget of the industrial project, and fulfill the quality of the industrial project, with a total of 256 correlations 
Table 1 Project critical factors

\begin{tabular}{|c|c|c|c|c|}
\hline Number & Critical factors & $\begin{array}{l}\text { Total number } \\
\text { of quotes }\end{array}$ & $\begin{array}{l}\text { Total percentage } \\
\text { of quotes }\end{array}$ & $\begin{array}{l}\text { Total percentage of articles } \\
\text { mentioning the factor }\end{array}$ \\
\hline 1 & Support from senior management & 61 & $5 \%$ & $72 \%$ \\
\hline 2 & Clear realistic objectives & 64 & $5 \%$ & $75 \%$ \\
\hline 3 & Strong/detailed plan kept up to date & 61 & $5 \%$ & $72 \%$ \\
\hline 4 & Good communication/ feedback & 40 & $3 \%$ & $47 \%$ \\
\hline 5 & User/client involvement & 39 & $3 \%$ & $46 \%$ \\
\hline 6 & Skilled/suitably qualified/sufficient staff team & 62 & $5 \%$ & $73 \%$ \\
\hline 7 & Effective change management & 55 & $5 \%$ & $65 \%$ \\
\hline 8 & Competent project manager & 56 & $5 \%$ & $66 \%$ \\
\hline 9 & Strong business case/ sound basis for project & 58 & $5 \%$ & $68 \%$ \\
\hline 10 & Sufficient/well allocated resources & 64 & $5 \%$ & $75 \%$ \\
\hline 11 & Good leadership & 44 & $4 \%$ & $52 \%$ \\
\hline 12 & Proven/familiar technology & 53 & $4 \%$ & $62 \%$ \\
\hline 13 & Realistic schedule & 24 & $2 \%$ & $28 \%$ \\
\hline 14 & Risks addressed/assessed/managed & 51 & $4 \%$ & $60 \%$ \\
\hline 15 & Project sponsor/champion & 21 & $2 \%$ & $25 \%$ \\
\hline 16 & Effective monitoring/control & 53 & $4 \%$ & $62 \%$ \\
\hline 17 & Adequate budget & 33 & $3 \%$ & $39 \%$ \\
\hline 18 & Organizational adaptation/ culture/structure & 57 & $5 \%$ & $67 \%$ \\
\hline 19 & Good performance by suppliers/contractors/consultants & 33 & $3 \%$ & $39 \%$ \\
\hline 20 & Planned close down/review/acceptance of possible failure & 46 & $4 \%$ & $54 \%$ \\
\hline 21 & Training provision & 53 & $4 \%$ & $62 \%$ \\
\hline 22 & Political stability & 15 & $1 \%$ & $18 \%$ \\
\hline 23 & $\begin{array}{l}\text { Correct choice/past experience of project management } \\
\text { of project management }\end{array}$ & 52 & $4 \%$ & $61 \%$ \\
\hline 24 & Environmental influences & 16 & $1 \%$ & $19 \%$ \\
\hline 25 & Past experience (learning from) & 50 & $4 \%$ & $59 \%$ \\
\hline 26 & $\begin{array}{l}\text { Project size (large)/level of complexity (high)/number } \\
\text { of people involved (too many)/duration (over } 3 \text { years) }\end{array}$ & 34 & $3 \%$ & $40 \%$ \\
\hline 27 & Different viewpoints(appreciating) & 13 & $1 \%$ & $15 \%$ \\
\hline
\end{tabular}

Table 2 Basic SEM Notation [8] (Cea. 2004)

\begin{tabular}{lll}
\hline Variable & Matrix zymology & Description \\
\hline $\mathrm{Y}$ & $\mathrm{Y}$ & Observable dependent variable \\
$\mathrm{X}$ & $\mathrm{X}$ & Observable independent variable \\
$\lambda$ & $\wedge$ & $\begin{array}{c}\text { Coefficient between variables } \\
\text { (observed or latent) }\end{array}$ \\
$\varepsilon$ & $\theta \varepsilon$ & Associated error to $\mathrm{Y}$ \\
$\delta$ & $\theta_{\delta}$ & Associated error to X \\
$\xi$ & $\xi$ & Independent latent variable \\
$\eta$ & $\eta$ & Dependent latent variable \\
$\zeta$ & $\Psi$ & Associated error to $\eta$ \\
$\beta$ & $\mathrm{B}$ & Coefficient between latent dependent \\
& & variables \\
$\gamma$ & $\Gamma$ & Coefficient between latent independent \\
& & variables \\
$\varphi$ & $\phi$ & Covariance matrix associated to $\xi$ \\
\hline
\end{tabular}

for evaluation; the most significant correlations are indicated as long as their $P$ value is greater than 0.01 , a total of 11 critical factors to consider for model building as shown in Table 6 .

\subsection{Development of a good theoretical model}

Resulting from the theoretical analysis of the factors through meta-analysis, classified by frequency and empirical results, obtained from surveys conducted in companies of the region, then evaluated by statistical tools such as exploratory factor analysis and confirmatory factor analysis to determine the structural equations where success criteria are also related. In Fig. 4, we can see the first structural model proposed and the most important critical factors regarding BUDGET (P.E.B.B) QUALITY (C.M.P.) and TIME (T.O.M.S.). 
Fig. 3 Example of structural equation model [7] (Cea, 2004)

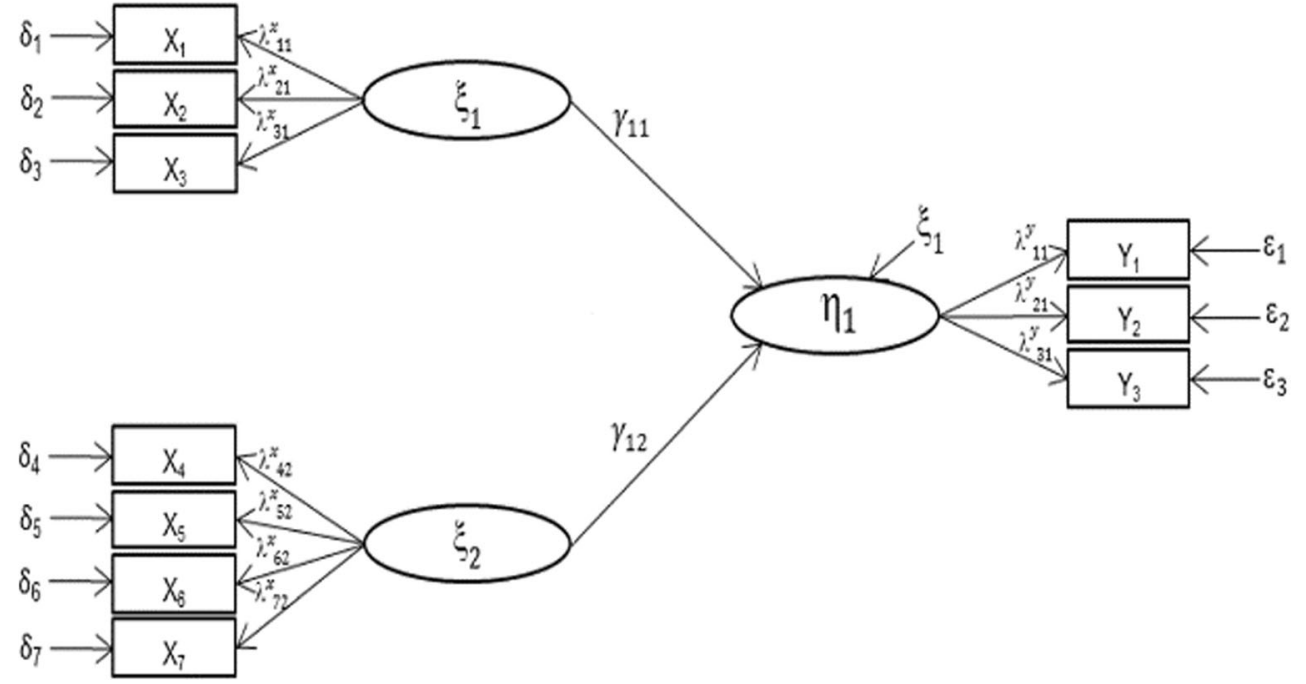

Table 3 Correlations for the latent variable 'fulfill the budget of the industrial project

\begin{tabular}{lll}
\hline & & T. SUPPORT \\
\hline T. PLAN & Person correlation & $.342^{* *}$ \\
& Sig. (two-tailed) & 0.000 \\
& & T. TECHNOLOGY \\
T. MANAGER & Person correlation & $.387^{* *}$ \\
& Sig. (two-tailed) & 0.000 \\
& & T. OBJECTIVES \\
T. EFFECTIVE & Person correlation & $.262^{* *}$ \\
& Sig. (two-tailed) & 0.000 \\
& & T. MANAGER \\
T. TECHNOLOGY & Person correlation & $.386^{* *}$ \\
& Sig. (two-tailed) & 0.000 \\
& & T. MANAGER \\
T. KNOWLEDGE & Person correlation & $.386^{* *}$ \\
& Sig. (two-tailed) & 0.000 \\
\hline
\end{tabular}

Table4 Correlations for the latent variable fulfill the quality of the industrial project'

\begin{tabular}{lll}
\hline & & Q. PERSONAL \\
\hline Q. PLAN & Person correlation & $.310^{* *}$ \\
& Sig. (two-tailed) & 0.000 \\
& & Q. MANAGEMENT \\
Q. SUPPLY & Person correlation & $.342^{* *}$ \\
& Sig. (2-taild) & 0.000 \\
& & Q. COMMUNICATION \\
Q. PARTICIPATION & Person correlation & $.375^{* *}$ \\
& Sig. (two-tailed) & 0.000 \\
\hline
\end{tabular}

\subsection{Factor analysis}

Factor analysis divides the variance of each indicator in two parts: (1) "common variance;" the variance explained by the latent (s) variable (s), which it is estimated on the basis of shared variance with other indicators in the analysis; and (2) "unique variance" which is a combination of a specific reliable variance for the indicator and a random error variance. There are two types of model-based analysis for common factors: exploratory factor analysis (EFA) and confirmatory factor analysis (CFA), both tests are designed to reproduce the observable relationships between a set of indicators with a small set of latent variables.

However, EFA and CFA differ mostly in the number and nature of specifications and restrictions in the measurement model for the latent variable.

Table 5 Correlations for the latent variable fulfill the budget of the industrial project

\begin{tabular}{lll}
\hline & & B. PLAN \\
\hline B. BUSINESS & Person correlation & $.340^{* *}$ \\
& Sig. (two-tailed) & 0.000 \\
& & B. BUSINESS \\
B. PERSONAL & Person correlation & $.355^{* *}$ \\
& Sig. (two-tailed) & 0.000 \\
& & B. EFECTIVE \\
B. COMMUNICATION & Person correlation & $.362^{* *}$ \\
& Sig. (two-tailed) & 0.000 \\
& & B. BUDGET \\
B. RISK & Person correlation & $.341^{* *}$ \\
& Sig. (two-tailed) & 0.000 \\
\hline
\end{tabular}


Table 6 Critical success factors according to the bivariate correlation value

Highest correlation indicators

\begin{tabular}{|c|c|c|c|c|}
\hline No & Critical success factors & Correlation & Critical success factors & $P$ value \\
\hline 1 & Competent project manager & 0.386 & Proven/familiar technology & $P<0.01$ \\
\hline 2 & Good communication/feedback & 0.375 & User/client involvement & $P<0.01$ \\
\hline 3 & Effective monitoring/control & 0.362 & Good communication/ feedback & $P<0.01$ \\
\hline 4 & Strong business case/ sound basis for project & 0.355 & Support from senior management & $P<0.01$ \\
\hline 5 & Proven/familiar technology & 0.347 & Training provision & $P<0.01$ \\
\hline 6 & Support from senior management & 0.342 & Strong business case/ sound basis for project & $P<0.01$ \\
\hline 7 & Effective change management & 0.342 & Training provision & $P<0.01$ \\
\hline 8 & Adequate budget & 0.341 & Risks addressed/assessed/managed & $P<0.01$ \\
\hline 9 & Strong business case/ sound basis for project & 0.340 & Support from senior management & $P<0.01$ \\
\hline 10 & Skilled/suitably qualified/sufficient staff team & 0.310 & Strong business case/ sound basis for project & $P<0.01$ \\
\hline 11 & Clear realistic objectives & 0.262 & Effective change management & $P<0.01$ \\
\hline
\end{tabular}

Reference: correlation matrix

*Correlation is significant at level 0.01

*Correlation is significant at level 0.05

EFA is data-driven, there are no specifications in relation to the number of common factors or the relationships array between common factors. Researchers use the EFA as a descriptive technique to determine the appropriate number of common factors, and to check, according to measurement, which variables are reasonable indicators for latent dimensions. In CFA, the researcher specifies in advance the number of factors and load pattern expected for indicators, as well as other parameters, such as independence or covariance factors and unique variances and indicators

\subsection{Exploratory factor analysis}

Exploratory factor analysis is a statistical approach to determine the correlation between variables in a dataset. This type of factor analysis provides a structure (grouping of variables based on the strong correlations). In general, an EFA prepares the variables to be used and clean the structural equation models. An EFA should always be conducted for new datasets.

The advantage of an EFA on a CFA is that no theory is applied to the elements fitting a construct. This means that the EFA is able to detect problematic variables more easily than CFA. In this section, we will develop EFA for this research.

\subsubsection{Explained variance matrix by the method of principal components}

The variance matrix (Table 7) is explained by the principal method components, the Initial Eigen values columns of the table display the variance explained by the initial solution, only 11 major factors have a total column value greater than 1 ; eigenvalues represent almost $55 \%$ of the variance for the original independent variables. This suggests that the three latent influences are associated with the factors, but there is room for a lot of unexplained variations.

The loads' extraction sums squared section shows the variance explained by the factors taken before rotation. The cumulative variability explained by three factors is about $30 \%$, a difference of $10 \%$ of the initial solution, this variation explains that the initial solution is missing a latent factor, indicating that the original variables and variability cannot explain the phenomena with precision. The rightmost section of this table shows the variance explained by the factors extracted after rotation.

\subsubsection{KMO and Barlett's test}

These tables show two tests which indicate the suitability of the data to detect the structure (Table 8,9). The sample
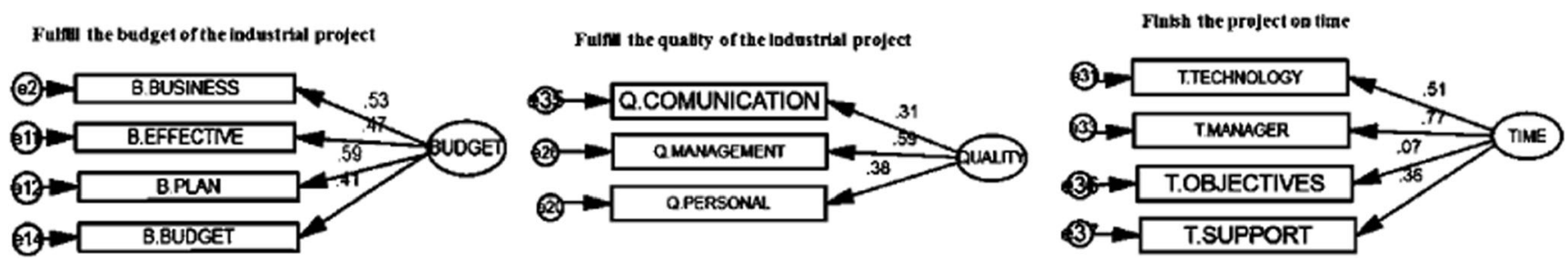

Fig. 4 Path diagram proposed form for structural model 
Table7 Total explained variance matrix

Total explained variance

\begin{tabular}{|c|c|c|c|c|c|c|c|}
\hline \multirow[t]{2}{*}{ Component } & \multicolumn{3}{|c|}{ Initial Eigen values } & \multicolumn{3}{|c|}{ Loads extraction sums squared } & \multirow{2}{*}{$\begin{array}{l}\text { Loads rotation } \\
\text { sums squared } \\
\text { Total }\end{array}$} \\
\hline & Total & $\%$ Variance & $\%$ accumulated & Total & $\%$ Variance & $\%$ accumulated & \\
\hline 1 & 8.350 & 17.766 & 17.766 & 8.350 & 17.766 & 17.766 & 7.201 \\
\hline 2 & 3.844 & 8.178 & 25.944 & 3.844 & 8.178 & 25.944 & 5.347 \\
\hline 3 & 2.088 & 4.443 & 30.387 & 2.088 & 4.443 & 30.387 & 5.100 \\
\hline 4 & 1.842 & 3.919 & 34.306 & & & & \\
\hline 5 & 1.744 & 3.710 & 38.016 & & & & \\
\hline 6 & 1.568 & 3.335 & 41.351 & & & & \\
\hline 7 & 1.479 & 3.147 & 44.497 & & & & \\
\hline 8 & 1.390 & 2.958 & 47.456 & & & & \\
\hline 9 & 1.266 & 2.695 & 50.150 & & & & \\
\hline 10 & 1.175 & 2.501 & 52.651 & & & & \\
\hline 11 & 1.122 & 2.386 & 55.037 & & & & \\
\hline 12 & 1.088 & 2.316 & 57.363 & & & & \\
\hline 13 & 1.037 & 2.206 & 59.559 & & & & \\
\hline 14 & 1.013 & 2.156 & 61.715 & & & & \\
\hline 15 & 0.974 & 2.072 & 63.787 & & & & \\
\hline 16 & 0.946 & 2.012 & 65.799 & & & & \\
\hline 17 & 0.917 & 1.950 & 67.749 & & & & \\
\hline 18 & 0.852 & 1.812 & 69.561 & & & & \\
\hline 19 & 0.820 & 1.744 & 71.306 & & & & \\
\hline 20 & 0.795 & 1.692 & 72.998 & & & & \\
\hline 21 & 0.787 & 1.675 & 74.673 & & & & \\
\hline 22 & 0.744 & 1.583 & 76.256 & & & & \\
\hline
\end{tabular}

Extraction method: principal components analysis

${ }^{\text {a }}$ When the components are correlated, the sums of squared added to obtain a total variance

measurement for Kaiser-Meyer-Olkin adequacy indicates the proportion of variance in the variables that may be caused by underlying factors. Higher values of 1.0 indicate that a factors analysis is suitable for the data; for values lower than 0.50 , the results of the factor analysis are unlikely to be useful.

\subsubsection{Pattern matrix}

The elements of this matrix are called weights or loads, they indicate the load between observed variable and factor. It

Table 8 Initial KMO

KMO and Bartlett's test

\begin{tabular}{ll}
\hline Kaiser-Meyer_olkin Measure of sampling Adequacy. & 0.789 \\
Bartlett's Test of Sphericity & \\
Approx. Chi-Square & 2922.314 \\
df & 1081 \\
Sig. & 0.000 \\
\hline
\end{tabular}

should be interpreted as standardized slopes (beta) resembling multiple regression analysis. Differences for the tables (Tables $10,11)$ show the modifications made through the exploratory factor analysis.

The solution for the Configuration Matrix must be interpreted by the performance method, similar to the matrix in the orthogonal rotated factors case. The oblique item is the most important of all matrices obtained; this is by setting "Matrix and Matrix" correlation between factors; it is essential to include it in the results analysis.

Table9 Final KMO

$\mathrm{KMO}$ and Bartlett's test

Kaiser-Meyer olkin Measure of sampling Adequacy.

0.799

Bartlett's Test of Sphericity

Approx. Chi-Square

1827.043

df

561

Sig. 
Table10 Initial pattern matrix

Pattern matrix

\begin{tabular}{|c|c|c|c|}
\hline & \multicolumn{3}{|c|}{ Component } \\
\hline & 1 & 2 & 3 \\
\hline Q. PALN & .646 & & \\
\hline Q. BUSINESS & .609 & & \\
\hline Q. KNOWLEDGE & .585 & & \\
\hline Q. COMMUNICATION & .564 & & \\
\hline Q. OBJECTIVES & .551 & & \\
\hline Q. PERSONAL & .548 & & \\
\hline T. SUPPORT & .515 & & \\
\hline Q. EFFECTIVE & .487 & & \\
\hline Q. RISK & .483 & & \\
\hline Q. MANAGER & .467 & & \\
\hline Q. PARTICIPATION & .459 & & \\
\hline T. OBJECTIVES & .455 & & \\
\hline Q. MANAGEMENT & .435 & & \\
\hline Q. BUDGET & .415 & & \\
\hline Q. SUPPLY & .414 & & \\
\hline T. KNOWLEDGE & .404 & & \\
\hline T. EFFECTIVE & .396 & & \\
\hline Q. ADAPTATION & .390 & & \\
\hline Q. SUPPORT & .383 & & \\
\hline T. PLAN & .371 & & \\
\hline Q. TECHNOLOGY & .346 & & \\
\hline T. COMMUNICATION & .336 & & \\
\hline T. MANAGEMENT & .319 & & .301 \\
\hline B. KNOWLEDGE & & .678 & \\
\hline B. TECHNOLOGY & & .603 & \\
\hline B. BUSINESS & & .599 & \\
\hline B. PERSONAL & & .584 & \\
\hline B. SUPPORT & & .572 & \\
\hline B. MANAGER & & .571 & \\
\hline B. PARTICIPATION & & .570 & \\
\hline B. SUPPLY & & .561 & \\
\hline B. COMMUNICATION & & .560 & \\
\hline B. OBJECTIVES & & .532 & \\
\hline B. EFFECTIVE & & .496 & \\
\hline B. PLAN & & .489 & \\
\hline B. MANAGEMENT & & .488 & \\
\hline B. BUDGET & & .478 & -.303 \\
\hline B. RISK & & .417 & -.322 \\
\hline T. SUPPLY & & & .768 \\
\hline T. TECHNOLOGY & & & .727 \\
\hline T. ADAPTATION & & & .653 \\
\hline T. MANAGER & & & .442 \\
\hline T. RISK & & & .423 \\
\hline T. PERSONAL & & & .335 \\
\hline T. BUSINESS & & & .302 \\
\hline T. PARTICIPATION & & & \\
\hline T. BUDGET & & & \\
\hline
\end{tabular}

Extraction method: principal component analysis, rotation method: Promax with Kaiser normalization

${ }^{a}$ Rotation converged in 6 iterations

\subsection{Confirmatory factor analysis}

"Confirmatory Factor Analysis" (CFA) is a type of structural equation modeling that deals specifically with measured models, the relationship between observable measurements or "indicators" and latent variables or "factors." The models objective for latent variables is to set the number and the nature of the factors considered for the variance and

Table 11 Final pattern matrix

Pattern matrix ${ }^{\mathrm{a}}$

\begin{tabular}{|c|c|c|c|}
\hline & Comp & & \\
\hline & 1 & 2 & 3 \\
\hline B. KNOWLEDGE & .684 & & \\
\hline B. BUSINESS & .604 & & \\
\hline B. TECHNOLOGY & .601 & & \\
\hline B. PERSONAL & .593 & & \\
\hline B. COMMUNICATION & .586 & & \\
\hline B. PARTICIPATION & .572 & & \\
\hline B. SUPPORT & .572 & & \\
\hline B. MANAGER & .556 & & \\
\hline B. OBJECTIVES & .551 & & \\
\hline B. SUPPLY & .541 & & \\
\hline B. EFECTIVE & .504 & & \\
\hline B. PLAN & .497 & & \\
\hline B. MANAGEMENT & .483 & & \\
\hline B. BUDGET & .478 & & \\
\hline Q. BUSINESS & & .639 & \\
\hline Q. PLAN & & .617 & \\
\hline Q. KNOWLEDGE & & .601 & \\
\hline Q. OBJECTIVES & & .584 & \\
\hline Q. COMMUNICATION & & .558 & \\
\hline Q. PERSONAL & & .551 & \\
\hline Q. EFFECTIVE & & .527 & \\
\hline Q. RISK & & .509 & \\
\hline Q. MANAGER & & .507 & \\
\hline Q. PARTICIPATION & & .481 & \\
\hline Q. SUPPLY & & .464 & \\
\hline Q. MANAGEMENT & & .455 & \\
\hline T. EFFECTIVE & & .437 & \\
\hline T. OBJECTIVES & & .422 & \\
\hline T. KNOWLEDGE & & .420 & \\
\hline T. SUPPLY & & & .739 \\
\hline T. TECHNOLOGY & & & .703 \\
\hline T. ADAPTATION & & & .655 \\
\hline T. MANAGER & & .338 & .444 \\
\hline T. RISK & & & .438 \\
\hline
\end{tabular}

Extraction method: principal component analysis, rotation method Promax with Kaiser normalization

${ }^{\text {a }}$ Rotation converged in 4 iterations 
covariance by a kit of indicators or $\mathrm{CF}$. One latent feature is an unobservable variable that has greater influence than an observable measurement and is considered for correlations across the model.

\subsubsection{Goodness fit indices}

$P$ value is a common index used in sociological research, a $P$ value of 0.05 is considered as a threshold to define an effective or ineffective study. The obtained error can also be addressed by increasing the size of the sample, reducing the possibility that the obtained data is coincidentally rare.

Comparative fit index (CFI): A rule of thumb for CFI and other comparative fit indexes is a value greater than 0.90 , it can reasonably indicate a good fit in the researcher's model [9] (Bentler, 2006).

Root mean square error of approximation (RMSEA): The RMSEA is an index of "badness of fit" in which a value of 0 indicates better fit, RMSEA $\leq 0.06$ indicates close fit proximity, values between 0.06 and 0.08 suggest a reasonable fit error. And RMSEA $\geq 1$ suggests a poor fit [10] (Hoyle, 2012).

\subsubsection{Initial results: modification Index comparison}

Each parameter has a rate above certain preliminary modification index; not displayed modification indexes indicate that they do not exceed the specified threshold. At this point, the initial results established an initial proposed model with its regression loads and the goodness fit indexes are shown in the Fig. 5. Figure 6 illustrates the comparisons between indexes for goodness of fit for the three structural models. Initial model shows a $P$ value (Table 12 ) for an effective study, RMSEA (Table 13) that indicates a close fit proximity, and a CFI (Table 14) close to a reasonable error fit.

\subsubsection{Partial results: covariation of $C F$}

For this partial model, the error variables $e 31$ and $e 33$ were covariate (Fig. 7) as the modification indexes showed the

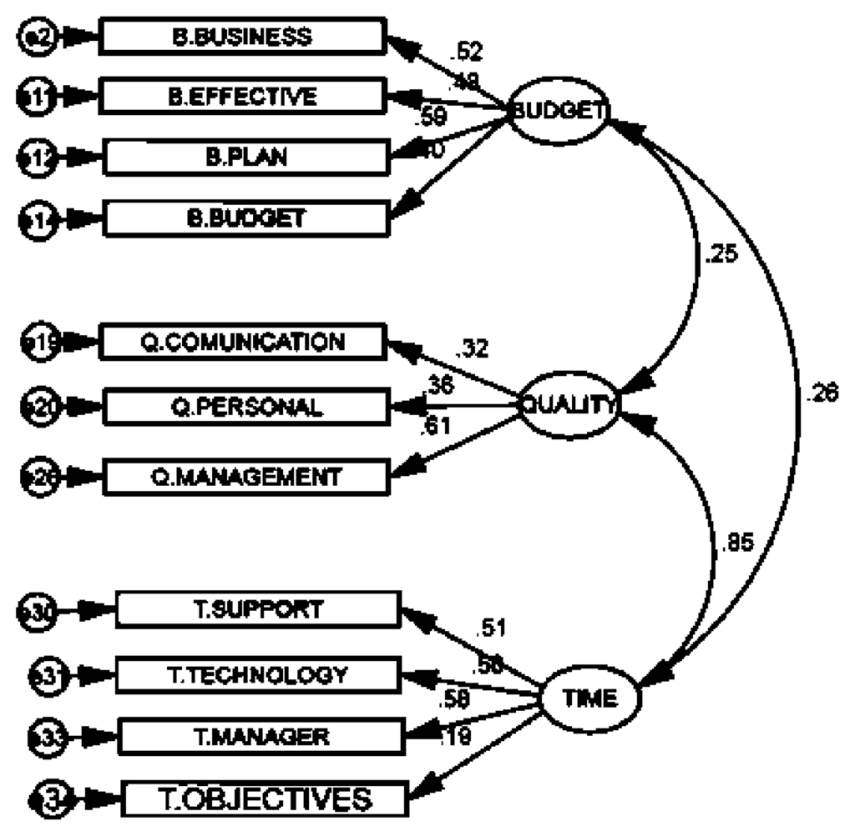

Fig. 5 Initial model and its standardized estimations

highest relation between them in Table 15. This generate a better modeling fit compared with the initial model, tables for goodness fit indices confirm the improvement since the CFI and RMSEA improved (Tables 16, 17, and 18).

In Table 19, we can see the high relation among error variables $e 26$ and $e 31$, however is impossible to covariate them because they are in different indicators sets. Regression loads and goodness fit indexes for the partial model are shown next (Fig. 7). Figure 8 illustrates the comparisons between indexes for goodness of fit that the structural model displays regarding $P$ value, RMSEA, and CFI to previous comparison.

\subsubsection{Simulation of fourth variable final results}

Figure 9 shows the construction for regression loads model with fore latent factors, adding an additional simulated latent variable (success). Tables 20 and 21 indicated the regression loads for each relation with in the model; also, the three goodness of fit indicators show an improved proportion compared to the previous models in Tables 22, 23, and

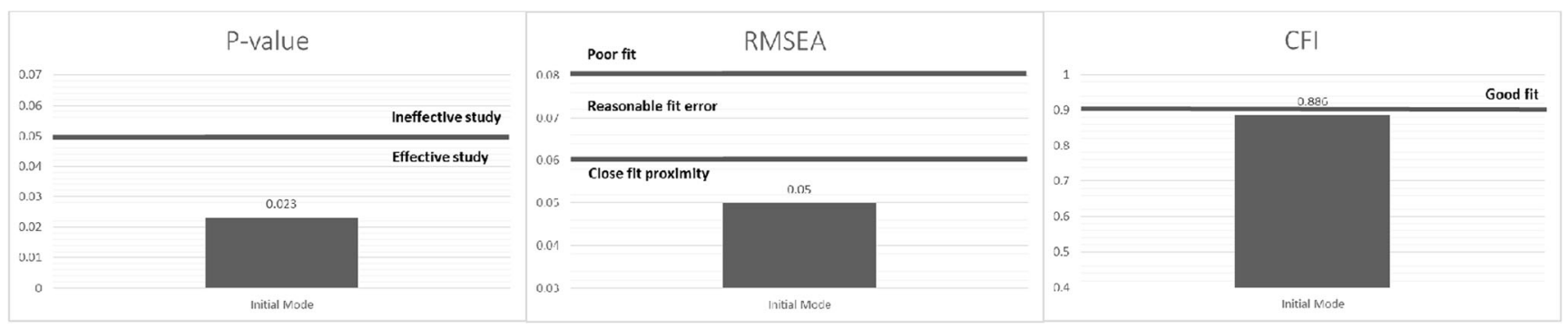

Fig. 6 Comparison of goodness fit indexes for proposed comparative initial structural model 
Table 12 Initial $P$ value

\begin{tabular}{llllll}
\hline Model & NPAR & CMIN & DF & $P$ & CMIN/DF \\
\hline Default model & 25 & 61 & 41 & 0.023 & 1.488 \\
Saturated model & 66 & 0 & 0 & & \\
Independence model & 11 & 231.196 & 55 & 0 & 4.204 \\
\hline
\end{tabular}

Table 13 Initial CFI

\begin{tabular}{llllll}
\hline Model & $\begin{array}{l}\text { NFI Delta } \\
1\end{array}$ & $\begin{array}{l}\text { RFI rho } \\
1\end{array}$ & $\begin{array}{l}\text { IFI Delta } \\
2\end{array}$ & $\begin{array}{l}\text { TLI rho } \\
2\end{array}$ & CFI \\
\hline Default model & 0.736 & 0.646 & 0.895 & 0.848 & 0.886 \\
Saturated model & 1 & & 1 & & 1 \\
Independence model & 0 & 0 & 0 & 0 & 0 \\
\hline
\end{tabular}

Table 14 Initial RMSEA

\begin{tabular}{lllll}
\hline Model & RMSEA & LO 90 & HI 90 & PCLOSE \\
\hline Default model & 0.05 & 0.019 & 0.074 & 0.486 \\
Independence model & 0.127 & 0.11 & 0.144 & 0 \\
\hline
\end{tabular}

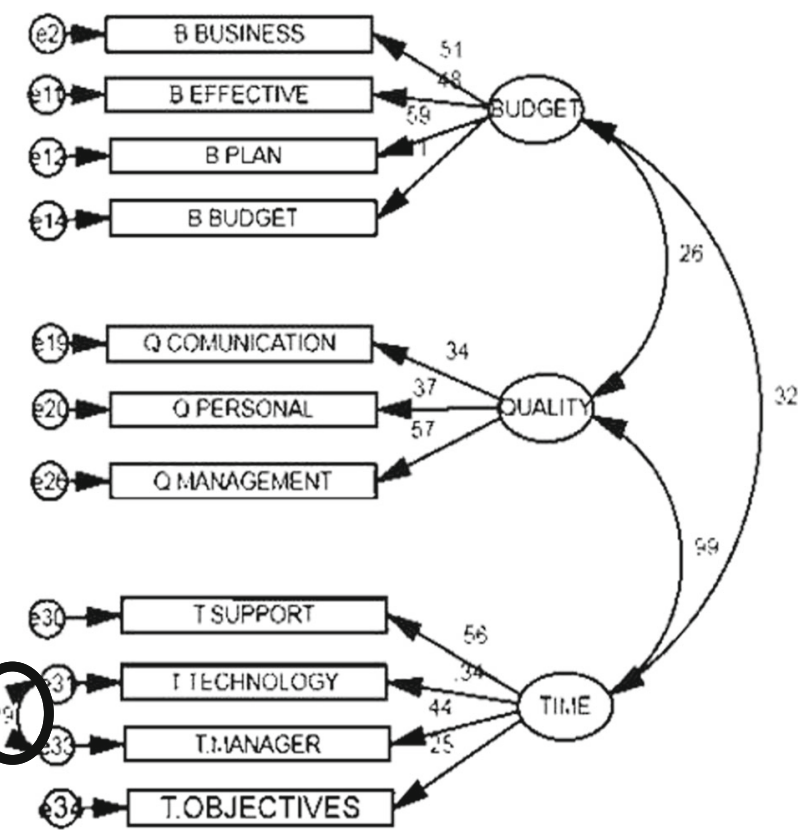

Fig. 7 Partial model and its standardized estimations
Table 15 Initial modification indices

\begin{tabular}{lllll}
\hline & & & M.I. & \multicolumn{1}{l}{$\begin{array}{l}\text { Par } \\
\text { Change }\end{array}$} \\
\hline e34 & $\longrightarrow->$ & BUDGET & 4.2170 .053 & \\
e31 & $\longrightarrow->$ & e33 & 6.342 & 0.115 \\
e20 & $\longrightarrow->$ & e31 & 5.398 & -0.1 \\
e19 & $\longrightarrow->$ & e34 & 4.661 & 0.069 \\
e14 & $\longrightarrow->$ & e31 & 5.901 & -0.103 \\
e12 & $\longrightarrow->$ & e34 & 5.212 & 0.078 \\
\hline
\end{tabular}

Table 16 Partial $P$ value

\begin{tabular}{llllll}
\hline Model & NPAR & CMIN & DF & P & CMIN/DF \\
\hline Default model & 26 & 49.327 & 41 & 0.148 & 1.233 \\
Saturated model & 66 & 0 & 0 & & \\
Independence model & 11 & 231.196 & 55 & 0 & 4.204 \\
\hline
\end{tabular}

Table 17 Partial CFI

\begin{tabular}{llllll}
\hline Model & $\begin{array}{l}\text { NFI } \\
\text { Delta 1 }\end{array}$ & $\begin{array}{l}\text { RFI } \\
\text { rho 1 }\end{array}$ & $\begin{array}{l}\text { IFI } \\
\text { Delta 2 }\end{array}$ & $\begin{array}{l}\text { TLI } \\
\text { rho 2 }\end{array}$ & CFI \\
\hline Default model & 0.0787 & 0.707 & 0.951 & 0.927 & 0.947 \\
Saturated model & 1 & 1 & 1 & & \\
Independence model & 0 & 0 & 0 & 0 & 0 \\
\hline
\end{tabular}

Table 18 Partial RMSEA

\begin{tabular}{lllll}
\hline Model & RMSEA & LO 90 & HI 90 & PCLOSE \\
\hline Default model & 0.034 & 0 & 0.063 & 0.794 \\
Independence model & 0.127 & 0.11 & 0.144 & 0 \\
\hline
\end{tabular}

Table 19 Partial modification indices

\begin{tabular}{lllll}
\hline & & & M.I. & $\begin{array}{l}\text { Par } \\
\text { Change }\end{array}$ \\
\hline e26 & $<->$ & e31 & 7.208 & 0.111 \\
e20 & $<->$ & e31 & 4.358 & -0.088 \\
e14 & $-->$ & e31 & 4.522 & -0.088 \\
e12 & $-\rightarrow$ & e34 & 4.806 & 0.074 \\
\hline
\end{tabular}




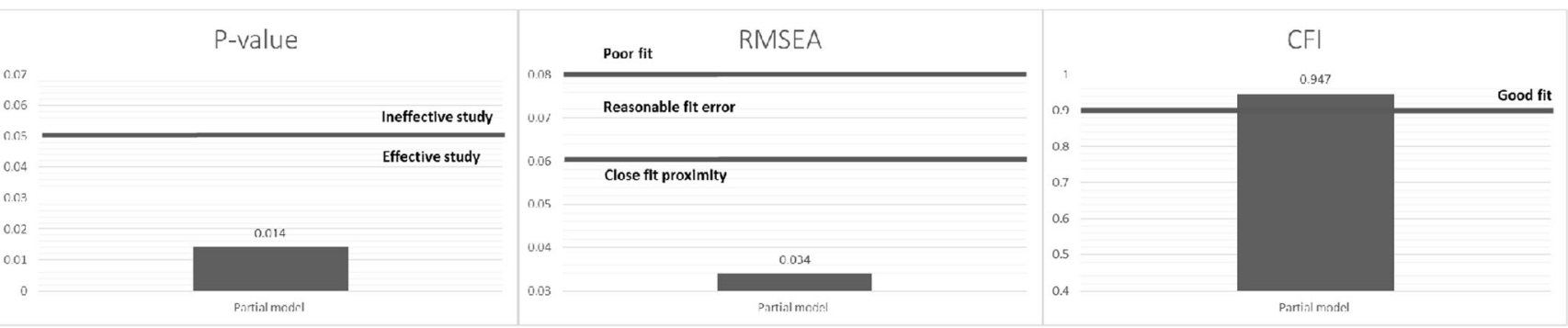

Fig. 8 Comparison of goodness fit indexes for proposed partial structural model

24. Figure 10 illustrates the comparisons between indexes for goodness of fit that the structural model displays regarding $P$ value, RMSEA, and CFI to the proposed partial structural model.

If the analysis is repeated the discrepancy between e 7 and e10 in Table 25 is reduced at least 5.013 for the covariance treatment as a free parameter, for the simulated latent variable run this $P$ value decreases to 0.032 . The correlation estimates and the standardized regression loads are re-calculated, as an example, when quality rises 1 for standard deviation, Q. COMMUNICATION is adjusted at 0.302 standard deviation on Table 21.

\subsection{Hypothetical regression structural equation modeling}

The traditional approach to integrating multiple regression analysis and factor analysis involves factoring a set of equations of one or more predictors and outcomes, generating fac- tor scores; also the creation of composited unit-weighted of the highest-loading indicators, using these variables as predictors or outcomes. SEM allows for these two components of the analytic strategy to be done simultaneously, at this point the relations between indicators, latent variables and the relations between variables are incorporated in a single model to be evaluated (Hoyle, 2012), here we develop the equation model for this research.

Regression equations:

$$
\text { BUDGET QUALITY TIME }
$$

$\mathrm{X}_{1}=\beta_{1}+\lambda_{1} \xi_{1}+\eta_{1} \quad \mathrm{X}_{5}=\beta_{5}+\lambda_{5} \xi_{5}+\eta_{5} \quad \mathrm{X}_{8}=\beta_{8}+\lambda_{8} \xi_{8}+\eta_{8}$ $X_{2}=\beta_{2}+\lambda_{2} \xi_{2}+\eta_{2} \quad X_{6}=\beta_{6}+\lambda_{6} \xi_{6}+\eta_{6} \quad X_{9}=\beta_{9}+\lambda_{9} \xi_{9}+\eta_{9}$ $\mathrm{X}_{3}=\beta_{3}+\lambda_{3} \xi_{3}+\eta_{3} \quad \mathrm{X}_{7}=\beta_{7}+\lambda_{7} \xi_{7}+\eta_{7} \quad \mathrm{X}_{10}=\beta_{10}+\lambda_{10} \xi_{10}+\eta_{10}$ $\mathrm{X}_{4}=\beta_{4}+\lambda_{4} \xi_{4}+\eta_{4} \quad \mathrm{X}_{11}=\beta_{11}+\lambda_{11} \xi_{11}+\eta_{11}$

Structural model:

$\eta_{1}=\beta_{12}+\xi_{1}+\beta_{13}+\xi_{2}+\beta_{23}+\xi_{3}+\xi_{1}$
Fig. 9 Final model regression loads between critical factors and the project success criteria

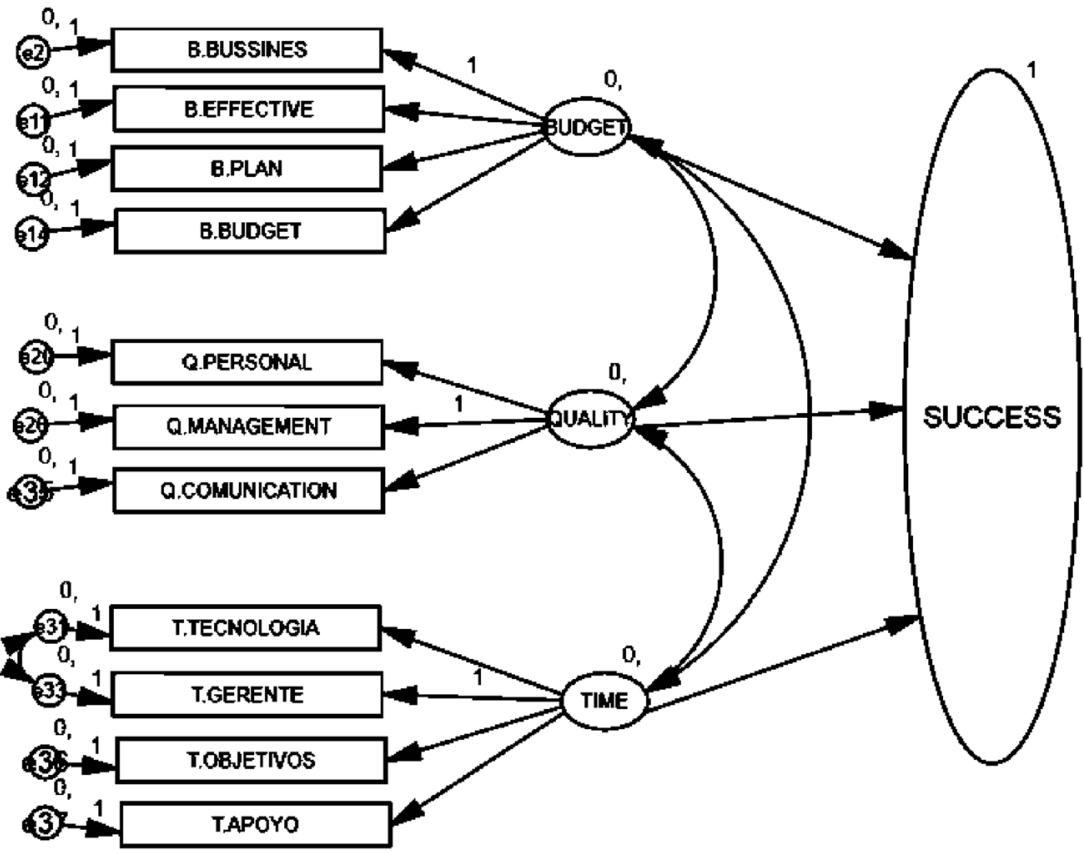


Table 20 The correlation estimates and the standardized regression loads

\begin{tabular}{lcc}
\hline & & Estimate \\
\hline B. STRONG BUSINESS CASE BASIS FOR PROJECT & $<-$ - BUDGET & 0.511 \\
B. EFFECTIVE MONITORING/CONTROL & $<-$ - BUDGET & 0.476 \\
B. STRONG/DETAILED PLAN KEPT UP TO DATE & $<-$ - BUDGET & 0.593 \\
B. ADEQUATE BUDGET & $<-$ - BUDGET & 0.409 \\
Q. GOOD COMMUNICATION/FEEDBACK & $<-$ - QUALITY & 0.343 \\
Q. SKILLED/SUITABLE QUALIFIED/SUFFICIENT STAFF/TEAM & $<-$ - QUALITY & 0.373 \\
Q. EFFECTIVE CHANGE MANAGEMENT & $<-$ - QUALITY & 0.567 \\
T. PrOVEn/FAMILIAR TECHNOLOGY & $<--$ TIME & 0.338 \\
T. COMPETENT PROJECT MANAGER & $<--$ TIME & 0.44 \\
T. SUPPORT FROM SENIOR MANAGEMENT & $<--$ TIME & 0.562 \\
T. CLEAR REALISTIC OBJEcTIVES & $<-$ - TIME & 0.253 \\
\hline
\end{tabular}

\section{Conclusions}

There are tests for goodness of fit with the confirmatory analysis for the greatest indicator loads or endogenous variables, bringing about which of the $\mathrm{CF}$ should be taken with more care while managing an industrial project; this is if we want to influence the subsequent results for the values for latent variables and improve conditions, consequently decrease the size of the error in each case of the endogenous variables (Table 24).

This contribution to the theory of project management is novel because applying meta-analysis intended for a large number of indicators filtered the most important final CF so they can be carefully chosen and described statistically by SEM methodology to quantify and qualify the relations among independent variables
Table 21 The correlation estimates and the standard regression loads

\begin{tabular}{lll}
\hline & & Estimate \\
\hline Q. COMMUNICATION & $<--$ QUALITY & 0.302 \\
Q. PERSONAL & $<-$ - QUALITY & 0.337 \\
Q. MANAGEMENT & $<--$ QUALITY & 0.524 \\
B. BUSINESS & $<-$ - BUDGET & 0.512 \\
B. EFFECTIVE & $<--$ BUDGET & 0.474 \\
B. PLAN & $<--$ BUDGET & 0.594 \\
B. BUDGET & $<--$ BUDGET & 0.406 \\
T. OBJECTIVES & $<--$ TIME & 1.238 \\
T. SUPPORT & $<--$ TIME & 0.496 \\
T. TECHNOLOGY & $<--$ TIME & 0.308 \\
T. MANAGER & $<--$ TIME & 0.377 \\
Q. COMUNICATION & $<--$ CLF & 0.104 \\
Q. PERSONAL & $<--$ CLF & 0.136 \\
Q. MANAGEMENT & $<--$ CLF & 0.321 \\
B. BUSINESS & $<--$ CLF & 0.049 \\
B. BUSINESS & $<--$ CLF & 0.015 \\
B. PLAN & $<--$ CLF & 0.002 \\
B. BUDGET & $<--$ CLF & 0.079 \\
T. OBJECTIVES & $<--$ CLF & -1.757 \\
T. SUPPORT & $<--$ CLF & 0.242 \\
T. TECHNOLOGY & $<-$ CLF & 0.2 \\
T. MANAGER & - CLF & 0.262 \\
\hline
\end{tabular}


Table 22 Final $P$ value

\begin{tabular}{llllll}
\hline Model & NPAR & CMIN & DF & $P$ & CMIN/DF \\
\hline Default model & 37 & 31.878 & 29 & 0.032 & 1.099 \\
Saturated model & 66 & 0 & 0 & & \\
Independence model & 11 & 231.196 & 55 & 0 & 4.204 \\
\hline
\end{tabular}

Table 23 Final CFI

\begin{tabular}{llllll}
\hline Model & $\begin{array}{l}\text { NFI } \\
\text { Delta 1 }\end{array}$ & $\begin{array}{l}\text { RFI } \\
\text { rho 1 }\end{array}$ & $\begin{array}{l}\text { IFI } \\
\text { Delta 2 }\end{array}$ & $\begin{array}{l}\text { TLI } \\
\text { rho 2 }\end{array}$ & CFI \\
\hline Default model & 0.862 & 0.738 & 0.986 & 0.969 & 0.984 \\
Saturated model & 1 & & 1 & & 1 \\
Independence model & 0 & 0 & 0 & 0 & 0 \\
\hline
\end{tabular}

Table 24 Final RMSEA

\begin{tabular}{lllll}
\hline Model & RMSEA & LO 90 & HI 90 & PCLOSE \\
\hline Default model & 0.022 & 0 & 0.06 & 0.864 \\
Independence model & 0.127 & 0.11 & 0.144 & 0 \\
\hline
\end{tabular}

Table 25 Final modification indices

\begin{tabular}{|c|c|c|c|c|}
\hline & & & M.I. & $\begin{array}{l}\text { Par } \\
\text { Change }\end{array}$ \\
\hline e7 & $<->$ & e10 & 5.013 & -0.092 \\
\hline e3 & 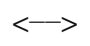 & e10 & 5.781 & 0.098 \\
\hline e2 & $<->$ & e10 & 4.506 & -0.089 \\
\hline
\end{tabular}

with respect to the latent variables with in a set of equations.

\section{Recommendations}

Indicators of interest were revealed in the survey of factors that are selected and defined as most important criteria this are the exogenous critical factors and the endogenous variable success. It is recommended to continue this research by adding and endogenous latent variable for customer satisfaction and the observable dependent variables for satisfaction, applying the matching methods to change the model, its trajectories, and the set of regression equations.

It is recommended to apply this methodology and replicate the research to test the generality of the model or in other sectors and industries; for manufacturing improvement projects, it can test their effect on product added value, employee performance, cost and quality for clients or other types of projects; for physiological research it is recommended to apply SEM as a test for the effect of lifestyle settings on health, educational institutions can use statistical equation modeling to find the didactic means that have an important association with student knowledge acquirement, regarding psychology this tool is able to find the mayor influences associated with personal happiness.

Open Access This article is distributed under the terms of the Creative Commons Attribution 4.0 International License (http:// creativecommons.org/licenses/by/4.0/), which permits unrestricted use, distribution, and reproduction in any medium, provided you give appropriate credit to the original author(s) and the source, provide a link to the Creative Commons license, and indicate if changes were made.
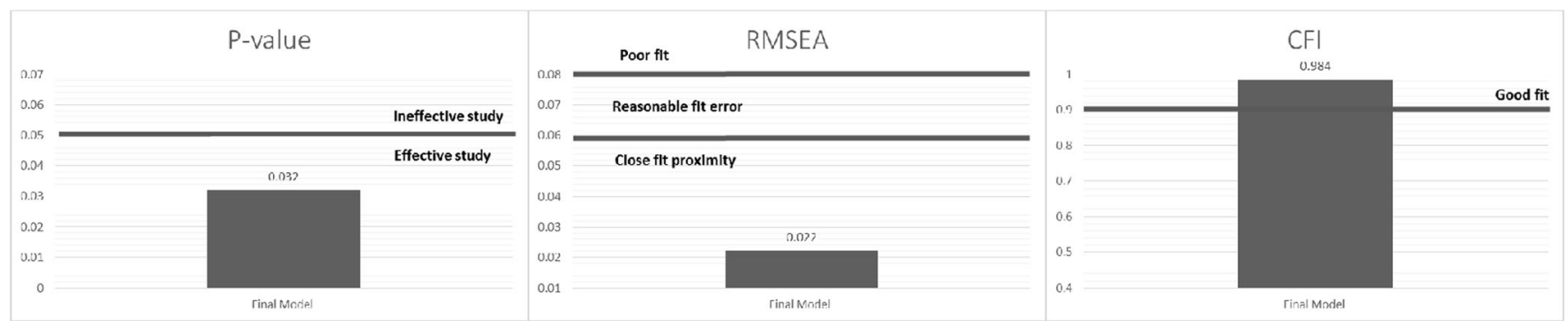

Fig. 10 Comparison of goodness fit indexes for final structural model 


\section{References}

1. Bentler HA (2006) Structural equation and log-linear modeling: a comparison of methods in the analysis of a study on caregivers' health. Retrieved from www.biomedcentral.com: http://www. biomedcentral.com/1471-2288/6/49

2. Cea MA (2004) Análisis multivariable. Teoría y práctica en la síntesis de la investigación social. [Multivariate analysis. Theory and practice in social research Synthesis.]. Madrid, España

3. Colín (2007) Tesis: Factores Organizacionales que Impactan en la Aplicación Exitosa de Células de Manufactura. [Thesis: Organizational factors impacting the successful implementation of manufacturing cells.]. Ciudad Juarez, México

4. Hoyle R (2012) Structural Equation Modeling Handbook. Guilford, New York, NY, USA

5. Iacobucci D (2009) Everything you always wanted to know about SEM (structural equation modeling) but were afraid to ask. J Consum Psychol, 673-680
6. Iacobucci D (2010) Structural equation modeling: fit indices, sample size, and advanced topics. J Consum Psychol, 90-98

7. Jenster V (1987) Using Critical Success Factors in Planing. Pergamon Journals Ltd., 102 to 109

8. Project Management Institute I (2004) Guía de los Fundamentos de la Dirección de Proyectos [Guide to Basics Project Management]. Retrieved from http://www.fnmt.es/: http://www.fnmt.es/ documents/10179/119827/Descargar+Documentaci\%C3\% B3n+-+Gesti\%C3\%B3n+de+Proyectos/b34b9d76-9e62-4fcbadbd-a0e5d675b4b4

9. Valles A (2008) Factores de Mayor Influencia en la Efectividad de Técnicas de la Manufactura Esbelta Tesis Doctoral [Major Factors Influencing the Effectiveness of Lean Manufacturing Techniques Thesis]. Ciudad Juarez, México

10. Wright SA (1999) Historical and critical commentaries on genetics. James F. Crow and William F. Dove, Madison, Edited 4 